\title{
From Riches to Rags: A Narrative Approach to Entrepreneurs' Experience of Venture Failure
}

\begin{abstract}
This paper investigates entrepreneurs' experience of stigma associated with venture failure. We implement a narrative approach to understand how stigma was experienced personally by entrepreneurs. Findings draw on the lived experience of 12 entrepreneurs and tell a collective story of what stigma meant and how it affected entrepreneurs' actions, behaviors, and decisions as they anticipated, enacted, and moved beyond venture failure. Overall the paper shifts the focus of stigma research from the socio-cultural perspective that constitutes the bulk of research to date, to the level of the microprocesses underlying these socio-cultural trends. Importantly, findings show how entrepreneurial failure engendered epiphanies or sudden deep insights for entrepreneurs that ultimately transformed failure from a very negative to a positive life experience. This transformation inspired entrepreneurs to contribute their knowledge gained through failure to future entrepreneurial efforts, even if these efforts were not their own. We discuss implications of findings for failed entrepreneurs' future start-ups and for the application of learning from venture failure.
\end{abstract}

Keywords: entrepreneurial failure, failure stigma, narrative inquiry 
Scholars increasingly recognize entrepreneurial failure as an important phenomenon given its implication for entrepreneurs and their role in job and wealth creation. Existing research explores the impact of failure on entrepreneurs (Shepherd 2003; Shepherd, Wiklund \& Haynie 2009) and offers insight into processes whereby failure is made sense of (Cope 2005; Cope \& Watts 2000), responded to (Singh, Corner \& Pavlovich, 2007), and learned from (Cope 2011; Huovinen \& Tihula 2008). Within this burgeoning literature, scholars introduce the notion of stigma (defined below) associated with entrepreneurial failure (Politis \& Gabrielsson 2009; Cardon, Stevens \& Potter, 2011). Stigma can trigger negative media hype and harsh criticism of unsuccessful entrepreneurs (Cardon et al. 2011) potentially deterring subsequent venture startups (Kirkwood 2007; Politis \& Gabrielsson 2009). Fewer start-ups compromise economic progress (McKeon, Johnston \& Henry 2004; Warren, 2004) and, we contend, threaten the loss of learning from failure that Cope (2011) and others have identified (Cope \& Watts, 2000; Singh et al., 2007). Stigma also has captured the attention of policy makers giving rise to, for example, the European Commission’s “Second Chance” policy that attempts to reduce its negative effects (European Commission Enterprise and Industry Group 2011).

To date, research predominantly examines stigma at the societal level. Empirical findings reveal socio-cultural stigma in specific countries and show their relationship to outcomes such as interest in entrepreneurship (Begley \& Tan, 2001) and entrepreneurial risk taking (Damaraju, Barney \& Dess 2010). Taken collectively, this quantitative research reveals generalizable relationships characteristic of the wider social context within which failed entrepreneurs make decisions about future entrepreneurial endeavors. However, we know little about the microprocesses underlying these societal level relationships. Stated differently, researchers have yet to explore how social stigmatization affects individual entrepreneurs' 
actions, behaviors, and decisions during and after venture failure. Moreover, individual entrepreneurs may engage in self-stigmatization since they intertwine their identities with venture outcomes (Cardon et al. 2005) and see their businesses as extensions of themselves (Shepherd et al., 2009).

The purpose of this paper is to empirically explore the stigma of entrepreneurial failure at the individual level. In particular, we seek to understand failure stigmatization from the perspective of entrepreneurs who have experienced it. We thus address the research question 'How do entrepreneurs experience stigmatization by self and others when their ventures fail?' We implement a qualitative, narrative approach to examine the question. Narrative organizes and gives meaning to narrators' experience of events (Creswell, 2007; Elliot, 2005); meaning making can be a core driver of the entrepreneurial process (Garud \& Giuliani, 2013). Importantly, narrative illuminates mechanisms underlying generalized relationships surfaced through quantitative research, showing how individual agency coalesces over time to give rise to the macro level relationships surfaced through quantitative research (Elliot, 2005; Garud \& Giuliani, 2013). Narrative also shows process and change over time and may reveal epiphanies that potentially alter the fabric of individuals' lives in ways that are unexpected (Denzin, 1989). A narrative approach to entrepreneurship research is on the rise and is particularly good at revealing how entrepreneurs generate and modify their vision of the future (Gartner, 2007). All told, narrative research on stigmatization due to venture failure can enhance our understanding of entrepreneurs' decisions about future start ups and the application of learning from failure. In the following sections, we present a background to the study, describe research methods, present findings, and discuss implications for the wider entrepreneurship literature. 


\section{BACKGROUND}

Stigma is generally defined as a mark of disgrace or infamy, a stain on one's reputation. Academically it has been described as something deeply discrediting that reduces the individual bearing the stigma "from a whole and usual person to a tainted, discounted one” (Goffman 1963, p. 3). More recently, Link and Phelan (2001) provided a comprehensive description of stigma as a concept made up of interrelated elements of "labeling, stereotyping, separation, status loss, and discrimination” (p. 377) and indicated that stigma can have a substantive impact on many areas of a person's life such as income, housing, and health (Link \& Phelan 2001).

Research on stigma is located mainly in the health and psychology literatures where studies are conducted to examine the nature and impact of and coping strategies used to deal with stigma in a variety of life contexts (Roca 2010). These contexts include physical (Fife \& Wright, 2000) and mental illness (Kroska \& Harkness 2006; Markowitz 1998), sexual orientation (Hereck, Gillis \& Cogan 2009), and criminality (Rasmusen1996; Schnittker \& John 2007). Corrigan et al. (2010) said that stigma can be of two types: social and self-stigma. Social stigma involved discrimination at the hand of others due to illness, for example. The authors suggested such stigmatization is a means of endorsing specific stereotypes within society. Self-stigma entailed a person discrediting him or herself, thereby endorsing the negative beliefs held by society (Corrigan et al. 2010). Similarly, other scholars described self stigmatization as the negative reaction of a person to him/herself in the light of personal experience (Knight, Wykes \& Hayword 2003).

Within management research, scholars examined the social stigma of failure in the corporate context. Wiesenfeld, Wurthmann \& Hambrick (2008) stated that stigma is the defamation of corporate executives because of their association with a failed company. For 
example, leaders of failed organizations are sometimes viewed as unsuitable and unskilled (Sutton \& Callahan 1987). Furthermore, executives’ stigmatization sometimes went further than social disgrace (Semadeni et al. 2008) and involved the loss of economic and professional opportunities as well as ostracism from the corporate world (Wiesenfeld et al . 2008).

Regarding entrepreneurial failure and possible stigmatization, we see two themes surfacing in the few studies conducted to date. As previously stated, the first theme is that of socio-cultural aspects of failure stigmatization. Several studies showed that stigma of entrepreneurial failure can vary from one culture to another. For example, Begley and Tan (2001) found that the shame of entrepreneurial failure is stronger in East Asian countries than Anglo countries. Cave, Eccles and Rundle (2001) found entrepreneurs from Britain perceived greater societal stigma for failure than did US entrepreneurs. However, Cardon et al. (2011) showed that even within the US, entrepreneurs in certain regions still experience stigmatization due to venture failure. Vaillant \& Lafuente (2007) concluded that belief in the social stigma of entrepreneurial failure is a significant deterrent to entrepreneurial activity in Spain. Damaraju et al. (2010) compared collectivist and individualistic cultures and found collectivist cultures were less tolerant and more stigmatizing of failure thereby discouraging entrepreneurial risk taking. The authors also provided evidence that environmental dynamism (the extent to which environments are fast changing, innovative and uncertain) provided an important moderating effect on the link between culture, stigma and entrepreneurial risk taking.

The second theme in entrepreneurial stigmatization research is the focus on stigma related to bankruptcy ensuing from entrepreneurial failure. Such studies commonly apply a public policy perspective to bankruptcy related stigma. For example, Efrat (2006) examined the reasons behind the reduced stigma among the American public towards personal bankruptcy. 
The author found that historically the public perceived bankruptcy as a result of overconsumption or fraud and thus socially stigmatized bankrupted entrepreneurs. More recently however, Efrat's evidence showed the American public attributing bankruptcy to factors such as inflation, recession, lack of welfare, and lenders' performance so that bankruptcy has become more socially acceptable. The author also explained that the media, government, and legal profession all played a role in shaping the social perceptions about personal bankruptcy. As the media reported more bankruptcy cases, people perceived bankruptcy as commonplace and became more tolerant of it. The public also saw bankruptcies tolerable due to the growing number advertisements placed by attorneys offering bankruptcy services and the use of neutral labeling terms such as debt resettlement. Lee, Yamakawa, Peng and Barney (2011) study the influence of bankruptcy laws on entrepreneurship development around the world. Drawing on data from 29 countries, the authors found that "lenient” and "entrepreneur-friendly" bankruptcy laws led to a higher rate of new venture founding (p. 505).

Taken collectively, existing quantitative research on stigma paints a picture of some of the generalized relationships at work in the socio-economic contexts within which entrepreneurs experience venture failure. What is missing, however, is an understanding of the microprocesses undergirding these generalized relationships. We thus specifically examine how individual entrepreneurs experience stigmatization of failure and how it affects their actions, behaviors, and decisions during and after the demise of their businesses. Existing research implies that entrepreneurial failure and ensuing stigmatization would be a strongly negative experience for individual entrepreneurs. For example, failed entrepreneurs may well experience negative outcomes (already described) analogous to those endured by failed executives in the corporate context (Paetzold, Dipboye \& Elsbach 2008; Sutton \& Callahan 1987; Wiesenfeld et al. 2008). 
This seems especially likely since research shows that an entrepreneur's identity is closely intertwined with his/her venture (Cardon et al. 2005). When failure happens, an entrepreneur may experience a negative spiral of shame (Smith \& McElwee 2011), may hesitate in taking risks or adopting new ideas, lack confidence in making venture related decisions and even decide to permanently give up on future venture founding (Politis \& Gabrielsson 2009). For example, one of Cope’s (2011) failed entrepreneurs, Gill, felt isolated and unable to seek help from others due to her self-stigmatization. Similarly, bankrupt Swedish entrepreneurs saw themselves as "marginalized" and "unequal” to others who had not failed (Sellerberg \& Leppanen, 2012). We thus seek further understanding of entrepreneurial stigmatization at the level failed entrepreneurs lived experience. We wish to illuminate the microprocesses undergirding the social-cultural findings reported in the literature by exploring the research question of 'How do entrepreneurs experience stigmatization by self and others when their ventures fail?’' Our qualitative, narrative approach to the research facilitates a rich and nuanced understanding of individual entrepreneurs' experience of failure stigma and what this experience means for decisions about subsequent venture founding and the use of knowledge gained through failure.

\section{RESEARCH METHODOLOGY}

\section{Research Design and Context}

A qualitative design implementing a narrative approach was used for this study (Elliot, 2005). Qualitative research provides rich descriptions of processes (Richards, 2009), facilitates induction of patterns amenable to further quantitative research (Eisenhardt \& Graebner, 2007; Yin, 2003), and is recommended for entrepreneurship research (Cope, 2011; Jack \& Anderson, 2002). This design enabled us to flesh out individual level, microprocesses that undergird the stigmatization of entrepreneurial failure at the socio-cultural level identified in existing 
quantitative research. Within this broader qualitative design, we implemented a narrative approach consistent with a growing body of research in sociology (Elliot, 2005) and psychology (Creswell, 2007; Lieblich et al., 1998). Narrative is discourse that provides a clear sequential order which connects events in a meaningful way, thereby offering insights about peoples’ experiences (Hinchman \& Hinchman, 1997). It is a device of interpretation through which people make sense of themselves and their experiences and can contain accounts of transformation (change over time), some kind of ‘action' and characters, all of which are brought together in an overall 'plot' (Lawler, p. 242). Narratives are somewhat unique within qualitative methods given they contain temporal information about when and why certain events unfold and the effects of these events on subsequent happenings (Polkinghorne, 2003). It thus is ideally suited to illuminating process and factors proximal to outcomes (Elliot, 2005); outcomes being the founding of new ventures and the implementation of learning by failed entrepreneurs in this study. Narrative also reveals the connection between individual agency and the wider social context (Elliot, 2005) such as the process mechanisms that underlie the socio-cultural patterns of stigmatization identified in existing quantitative research on failure stigma. Moreover, a narrative perspective has been gaining ground in entrepreneurship research as seen in special issues and a dedicated journal (Venkataraman, Sarasvathy, Dew, Forster, 2013). We thus collected and analyzed entrepreneurs' stories of failure pertinent to the research question of "How do entrepreneurs experience stigmatization by self and others when their ventures fail?

The research context was New Zealand which has a high rate of entrepreneurial activity. In 2005, The Global Entrepreneurship Monitor reported New Zealand as third in terms of Total Entrepreneurial Activity at $17.6 \%$. This is greater than the USA in sixth position at $12.4 \%$ and the global average of 9.1\% (Fredrick \& Chittook, 2006, p.22). However, strong entrepreneurial 
activity is not the same as business acumen and there is evidence of higher than average failure rates and bankruptcy in this country (Lee et al., 2011). Moreover, the regulatory environment is not supportive of business failure with liquidation of the business being the most common outcome of insolvency (Kuruppu, Laswad \& Oyelere, 2003). This is contrasted with the debtororiented approach in the USA where insolvent organizations are encouraged to continue operating as a going concern (Franks, Nyborg \& Torous, 1996). The New Zealand context appears closer to that of the UK than the US in research examining bankruptcy laws and their effects in 29 countries (Lee et al., 2011).

\section{Sampling and Data Collection}

We employed purposive sampling selecting 12 entrepreneurs who had experienced the failure of their small to medium sized ventures (see Table 1). All participants were given false names for anonymity. Such sampling provided information-rich cases for in-depth study of the stigmatization experienced by entrepreneurs during venture failure and its aftermath (Cope, 2011). Moreover, a narrative approach ensured that each participant gave a fine-grained account of their lived experience of failure.

We collected data predominantly through interviews which lasted between 1.5 and 2 hours. Interviews are the typical method use for data collection in narrative research often being the sole source of data relied on (Creswell, 2009; Elliott, 2005; Lieblich et al., 1998). Our interviews were semi-structured with several open ended questions asking participants to tell the interviewer their story of venture failure. We thus took the particular narrative approach that focuses in on a specific episode in participants' lives as opposed to documenting life stories (Elliot, 2005). Interview data was augmented by field notes made by the first author as interviews were conducted. Moreover, we gathered additional, secondary sources of data where 
appropriate and available. These included media articles, website information, and email communication with the participants (Creswell 2009).

Insert Table 1 about Here

\section{Data Analysis}

We began by constructing chronologies for each entrepreneur's story of venture failure, looking for common elements (Creswell, 2009; Elliott, 2005). As such, evidence revealed a collective story of failed entrepreneurship and how stigmas were experienced as participants moved through the sequence of events that constituted failure and its aftermath. With a focus on stigma in particular, we identified patterns and meanings as articulated by participants. Once identified, we cycled back to interviews and tracked patterns through participants' narratives to verify patterns across participants and to identify nuances within patterns.

\section{FINDINGS}

How do entrepreneurs experience stigmatization by self and others when their ventures fail? Our evidence presents a "collective story" or a research account of a group, stigmatized entrepreneurs, whose narratives have yet to surface in the entrepreneurship literature (Richardson, 1990). This collective story can be divided into three episodes that roughly correspond to the conventional narrative structure of a transformational tale - complication of situation, climax, and resolution (Selden \& Fletcher, 2010). The first episode (complication of situation) we call "anticipating failure”. It represents the time period wherein entrepreneurs begin to see venture failure as likely because of the serious, seemingly irresolvable difficulties being experienced (partnership issues, financial losses, and legal problems). The second episode (climax) we label trysting failure and it covers the months within which failure actually 
unfolded. During this episode entrepreneurs were busy with discontinuing businesses, declaring bankruptcy, dissolving partnerships, and so forth. The third episode we mark as transforming stigma through action (resolution) and it entails entrepreneurs moving beyond the stigma they experienced due to venture failure. This third episode involved an epiphany in the collective story - entrepreneurs had deep insights about the meaning of their failures that transformed it into something positive. Moreover, entrepreneurs acted on epiphanies, trying to create change so that other entrepreneurs might avoid failure and escape stigmatization. Epiphanies can be revealed by narrative research and provide a nuanced understanding of how a particular phenomenon is experienced and given meaning (Denzin, 1989). The following subsections present these episodes and describe themes of stigmatization that occurred in each. It is important to note that stigmatization themes were not confined exclusively to the episode within which they are discussed below. For example, a theme could surface strongly in the anticipating failure episode and resurface again in the trysting failure episode. Similarly, a theme could be experienced in a minor way in an earlier episode but reoccur in a later episode much more strongly. We nevertheless present the stigmatization themes within the episodes where they surfaced most strongly for entrepreneurs and describe how these themes affected entrepreneurs' actions, behaviors, and decisions.

\section{First Episode: Anticipating failure}

Anticipating failure began when entrepreneurs started seeing the problems their ventures had as insurmountable. Participants unanimously described this episode as a demanding and highly stressful time. Entrepreneurs tried to prevent the venture from failing but most described reaching a point when failure seemed inevitable. This recognition was so "overwhelming" and "stressful" that it triggered serious personal consequences for some including panic attacks (Ian, 
Tania), hospitalization (Caleb, Ian) and even suicidal thoughts (Tania). The two stigmatization themes that surfaced strongly in this episode were "castigating self" and "expecting negative judgment”.

Stigma themes. The castigating self theme involved entrepreneurs criticizing and negatively judging themselves when the failure of their ventures began to seem inevitable. This was clearly self-stigmatization because participants mentally but continually applied negative labels and descriptions to themselves when anticipating failure. For example, Ken stated: "I was beginning to feel like a loser - like a failure.” David thought of himself as a "stupid” person and described himself as a "bad boy" who was about to "lose Mum’s money” (her investment in his business) because of his stupidity. Similarly, Tania reported thinking of herself as a failure even before her business collapsed. She described herself as stupid saying "I was dumb and stupid because I didn’t know what I was doing...I wasn’t business savvy... and I didn’t have any business ownership or management experience". She denigrated herself for having "started something that I could not make work". She further castigated herself by thinking "failure is a bad thing because there hasn't been much failure in my family”.

Entrepreneurs blamed themselves for their ventures being on the brink of collapse and castigated themselves for letting down family members. This can be seen in Ian’s comment, "I was letting people down, particularly my family.....I had convinced my wife that I could run the business successfully and that it was worth giving up a relatively secure job in the bank". Caleb made an analogous comment when he stated “I felt I wasn’t doing enough, I felt the pressure of my wife and kids and that was hard to live with because I tried to perform in order to protect them". 
The expecting negative judgment theme showed participants’ perceptions of others’ harsh opinions and poor treatment when their ventures were at risk of failure. Although we report entrepreneurs' perceptions, this theme conveys social stigmatization because it indicates expectation of treatment by others. Not surprisingly, entrepreneurs expected to be treated negatively by creditors. For instance, Nigella said she expected unpleasant reactions from creditors she could not afford to pay as her business failed. She described "feeling threatened by" and being "nervous for weeks about” these creditors. Similarly, Larry "expected a lot of backlash” from businesses that were not paid as his business was failing. Bob also expected that "people at the credit control” would "look at me in a different light" and judge him as someone who "didn’t pay the bills". Creditors were not the only group that entrepreneurs expected negative judgments from. They also expected prospective employers to perceive them negatively. Tania offers a good illustration of this when she stated that a "failed business" would "not look good on my CV (resume) when I apply for a job”. Bob also said that his bankruptcy "would not put me in a good state in the future for earning money". Poignantly, Tania identifies another group that she expected negative judgments from, family members. She feared her husband would "turn against her" due to the setback the "failed business" presented for their joint standard of living.

Stigma affecting actions, decisions, behaviors. Castigating self and expecting negative judgment affected entrepreneurs' actions, decisions and behaviors in this first episode of anticipating failure. In particular, entrepreneurs delayed or tried to avert impending failure as described by Paula. She admitted delaying the decision to end her venture because she was trying to avoid being stigmatized as a failed entrepreneur. She felt that the decision to close the business would damage her reputation and she wanted to continue enjoying her status of 
"successful” and "internationally recognized" entrepreneur. Paula stated that she "lost the house, the car, and everything else” and said the extent of this financial damage could have been minimized if she had "given up the business three years before". In the same way, Edward described how he "poured money into the business and tried to keep it going" in an effort to "save face". Edward stated: "We lost about $\$ 450,000$ but we could have come out of it probably only losing $\$ 150,000$ if I hadn’t been trying to save face”.

Entrepreneurs engaged in behavior to cover up the fact that their ventures were at serious risk of failure. Specifically, entrepreneurs tried to keep their ventures’ precarious positions secret from others because they feared being stigmatized. For example, Bob cited a "stigma of failure" as the reason he kept "ninety-nine percent of the negative information" regarding the state of the business as a "secret", even from his wife. He talked about the stigma of failure involving a loss of "pride"; he envisioned his friends as saying "poor Bob" and he wanted to avoid this if at all possible. He said loosing pride was almost as serious in his mind as "losing money" and the ability to "get credit and do something again in this small town". Nigella also talked about keeping the state of her troubled business secret. She stated that "for ages" she didn’t tell her "closest friends" that her business was on the brink of failure; despite the fact that they were almost all "business women”. She didn’t tell these friends that she "couldn’t even afford Christmas dinner” because of the financial losses she was experiencing.

Several entrepreneurs went beyond keeping secrets and actually lied in order to cover up the impending venture failure. David described having "tentacles of lies and deceit” running though "all his relationships" that formed a "little bubble protecting me when things started going wrong with the business". He admitted also lying to his wife to cover up the likely failure of the business. In a similar fashion, Jana spoke of "making up stories” that covered up the 
tenuous state of her business. She said she did this, in part, to "keep [her] image" of a successful entrepreneur intact.

Finally, entrepreneurs shunned professional help and potential social support as the venture started to show signs of failure. Matt said he felt "grief" when his venture looked likely to fail but stated he was "not very good about admitting vulnerability and seeking help". He was concerned that "seeking help has a stigma about it". Bob acknowledged that if he had shared the issues plaguing the business with someone then it "might have been easier to deal with the challenges” but he did not do so at the time. Entrepreneurs also tended to shun personal relationships thereby missing out on social support when they faced the potential failure of their ventures. For instance, Nigella “stopped dating” because she believed that she “didn’t have anything to offer anyone and didn't feel attractive anymore.” She even avoided shopping because she worried that creditors who she was not able to pay would approach her and criticize her for spending money that should be paid to them. David stated: "I stopped going to church because people there knew about me and my business." This finding provides a more fine grained understanding of the social distancing entrepreneurs engaged in due to venture failure than previous research. Past studies suggest that entrepreneurs distance themselves socially after the failure of their ventures (Singh et al., 2007; Cope, 2011) but current findings suggest this distancing begins before actual failure. Entrepreneurs experienced stigmatization when their venture started showing signs of failure. This finding, if corroborated by additional research, begs the question if failure could have been averted in some of these ventures if stigma had not been such a strong force shaping entrepreneurs' actions. Perhaps some failures could be avoided if practical interventions could be designed for implementation at what might be called "leading indicators” of venture failure. 
In sum, evidence from this first episode in entrepreneurs' collective story shows that the stigma of entrepreneurial failure arises earlier than has been revealed in previous research. Scholars have argued that stigma surfaces at the time of actual venture failure (Politis \& Gabrielsson, 2009) but our participants described in some detail how stigma surfaced prior to actual failure. Like Shepherd et al. (2009), we find that the negativity associated with failure surfaces in anticipation of it. Importantly, current evidence shows how the experience of stigma can contribute to venture failure in that it affected entrepreneurs' actions, decisions, and behaviors in ways that likely exacerbated ventures' problems. Actions and behaviors, in turn, shaped outcomes for entrepreneurs and their ventures. These outcomes are detailed in Table 2 for each episode in entrepreneurs' collective story.

Insert Table 2 about Here

\section{Second Episode: Trysting failure}

This episode encompasses the time period when entrepreneurs actually enacted venture closure or discontinuance. Practically speaking, our participants took legal, financial, and professional steps to discontinue their businesses. Entrepreneurs described this episode as a “terrible” (Paula) period that seemed like a "nightmare” (Ken) filled with "suffering” (Larry), “pain” (Larry), “difficult transitions” (Tania) and "struggle” (Ian). Participants were clear they experienced stigma while they engaged in the practical activities associated with closing ventures. Two stigmatization themes that featured prominently in this episode were "perceiving ostracism” and “doubting judgment”.

Stigma themes. The perceiving ostracism theme meant entrepreneurs felt shunned and ignored by people who had previously been a vital part of the community they interacted with 
while developing and managing their ventures. As implied by its name, this theme reflects social stigma in that entrepreneurs felt shunned by others in this episode. Interesting, they perceived ostracism from multiple groups, the first of which was bankers. Entrepreneurs described a spectrum of ostracism ranging from somewhat mild ignoring treatment to "harsh" shunning behavior. Ken describes the milder form of this behavior when he said bankers had no "patience”. In the same vein, others reported bankers as being "uncooperative” and claimed that the "banks didn’t understand" what the entrepreneurs were dealing with during this episode. Other participants spoke of a mindset that bankers had about entrepreneurs in the midst of failure. Caleb summarized this well when he stated that bankers only considered "their own selfish objectives". He argued that bankers should be "more lenient and understanding of the demands of my industry". He was extremely disappointed the bankers had only "looked at a situation from an accounting perspective”. At the other end of the spectrum, entrepreneurs experienced what they perceived as very harsh shunning from bankers, particularly when bankruptcy was declared. Nigella described how her bank "cancelled" her debit card (electronic funds transfer card that can be used at point of sale) on the day of bankruptcy without telling her in advance that this would be done. To access any money in her account, she was required to get approval from the bank manager. This involved her waiting in the lobby as a teller went to get the manager and bring him out to sign paperwork so she could access funds. Again, she had been unaware that this procedure would be enacted anytime she needed money to make ordinary purchases like groceries and clothing. She was deeply embarrassed by this procedure and spoke of feeling "hideous" when enduring it. She felt that other bank customers in the lobby were staring at her during these transactions. She felt the bankers should have treated her differently 
from bankrupts who lost their ventures due to extensive "personal lifestyle spending" because she was bankrupt due to "purely business reasons".

Also, entrepreneurs felt ignored and shunned by larger businesses (i.e., suppliers) as they tried to shut down their businesses. For example, David tried to arrange temporary credit with a large business but found he could not do so and lamented that larger “businesses don’t understand" the situation for entrepreneurs. Nigella approached a large corporate organization that she owed money to and explained her venture's predicament. She was relieved that the organization agreed to forgive her debt but later found out that this company had placed her on "blacklist” of people/ companies that the large company would no longer do business with. This experience along with several others convinced her that large businesses were very "hardnosed" and had "ridiculous and harsh rules concerning small businesses".

Sadly, entrepreneurs felt ostracized by friends and family. For example, Matt reported that his "family treated him differently", his "social circle changed" and his "friendships were not there any longer". Tania felt shunned by family members. They told her she was "being too negative” when she talked about her failed venture and "yelled and screamed” advice at her regarding shutting down the venture and moving on with her life. She was very clear that such treatment "did more harm than good" in that it "compounded” her feelings of being ostracized due to venture failure.

The doubting judgment theme encompasses entrepreneurs' lack of faith in their ability to make good decisions about the failing business and about their own futures. This is a self-stigma as seen in Ian's description of himself as he progressed through this episode. He claims he "lost complete confidence" in himself and "started to have self-doubts" about his "ability to be successful” in anything. Nigella said she was "not confident” about her "decision making 
ability” and “didn’t trust” her judgment because her “choices for the business hadn’t been great”. Tania described her self confidence as "murdered" with the failed venture. She explained that while shutting down her venture she was continually “doubting” herself and this was "killing her head". Similarly, Caleb said his confidence in his own decisions "went down with the failed business”.

This doubting judgment spilled over into participants’ personal lives. Entrepreneurs felt keenly responsible for the effect of the business failure on their families' lifestyle and income. Many entrepreneurs expressed a sentiment similar to Ian's who doubted whether or not he could be trusted to be "responsible" for himself and his family. Caleb and Tania also talked about how they "lacked confidence" in making family related decisions.

Stigma affecting actions, decisions, behavior. Evidence shows stigma in this episode affected actions, decisions, and behaviors in two ways. First, entrepreneurs continued to avoid socializing during this episode because of the ostracism they perceived from bankers and other businesses. Participants feared they would run into bankers or creditors at social events and have to experience the feelings of being shunned and ignored again. Second, entrepreneurs delayed subsequent career decisions due to self doubt. Nigella "spent months watching DVDs" and "doing nothing else" in order to avoid making decisions regarding her future. Ian also avoided any decisions regarding what he wanted to do next in his career by "staying long hours in bed" as he struggled with "overwhelming feelings of failure”. Tania had ideas about possible new business ventures but avoided thinking about these ideas because "things didn’t come right” for her failed business. She even didn't look at emails that her friend sent to her regarding ideas for another venture because she doubted her ability to make good decisions. 
In conclusion, this second episode of the collective story shows that entrepreneurs experienced social and self stigma when their ventures failed. In particular, the perceiving ostracism theme provides a more fine-grained description of social stigma experienced by entrepreneurs when ventures fail. Previous research focused on stigmatization inflicted at a socio-cultural level by the media (Cardon et al., 2011) but the present study reveals sources of stigma emanating from others that entrepreneurs interact with directly as they take steps to close their businesses. Future research is needed to systematically examine how individual entrepreneurs experience stigma from different sources and to identify which sources affect them most strongly and why.

\section{Interlude: Epiphany}

In between the second and third episode we place an interlude which captures the epiphanies or pivotal realizations entrepreneurs had regarding the stigma of entrepreneurial failure. Epiphanies can be part of an unfolding narrative (Denzin, 1989; Elliot, 2005) and are experiences which alter the fundamental meaning structures of a person's life (Denzin, 1989). Studied entrepreneurs had such experiences in that the very negative meanings attached to stigma failure in the first two episodes were transformed into positive meanings and experiences in the third episode of the collective story (presented below). This was an unexpected finding but entrepreneurs uniformly described profound realizations and moments of clarity that brought about a fundamental shift in how they perceived their experience of venture failure and themselves as a result of surviving failure. The transformations is described more completely in the third episode but is identified by this interlude to give a sense of the substantively reorienting nature of epiphanies in the collective story of studied entrepreneurs.

In particular, entrepreneurs described flashes of deep insight and realizations about how their own behavior and reaction to stigma had contributed to venture failure. They had moments 
where they acknowledged to themselves personal ego and attachment to material things helped to bring about venture demise. For example, David described how he "suddenly got the answer one day" as to why he went bankrupt -- he saw his lying as a direct cause of the failure. He realized he engaged in "self-deception" as well as lying to others and this shaped his behavior as an entrepreneur. He described boosting his ego and covering up his venture’s trouble by making generous donations to his church that were unaffordable. He made these donations in the name of the venture and believed they directly contributed to bankruptcy. Also, Ian recognized the role his ego had played in the failure of his venture. He realized he "gave too many discounts" to customers, that his ego had "enjoyed helping people" but that he went "overboard" and brought about the failure of the business.

Bob described being "too attached" to the symbolic trappings of venture success which boosted his "false sense of ego". He believed he got caught up in trying to "keep up" with his "peers". He indicated that attachment to his venture and its trappings of success interfered with his decision to exit the troubled venture. He could not bring himself to "let go" and further financial losses ensued. He came to see himself as having "gambled" by "throwing more money" into a failing business which only made things worse. He was forced to sell his house to pay outstanding venture debts and he found this "extremely difficult" due to an "attachment" to this material possession.

The depth and transformational potential of epiphanies is illustrated by the fact that several of the entrepreneurs described these pivotal moments as "spiritual”. For example, Ken related an experience in which he felt the presence of a "higher power" that gave rise to the insight that he would "get all the answers" to his questions about why his venture failed and what lay ahead in his life. Similarly, Jana came to see her venture’s failure as having spiritual 
significance in her life and the meaning she attached to it was one of "temporary transition period" despite the loss of the business being "very hard" for her. When interviewed, she believed she would start this business again and have a different result.

\section{Third episode: Transforming stigma}

This final episode captures the period after epiphany and reflects, as entrepreneurs moved on with their lives, the meaning participants created for themselves about their failure experiences and actions that grew out of those meanings. Entrepreneurs had gained profound realizations and deeper insights from their epiphanies so that in this episode they upended the stigma of failure and transformed the meaning of venture failure into something positive. Entrepreneurs took actions to challenge failure stigma which created feelings of "enthusiasm" (Larry), “dream” fulfillment (Bob \& Paula) and "meaning” (Ian and Matt). The two themes that surfaced strongly in this episode were "changing stigma and learning more about failure" and "pride in hard but ethical decisions".

Transforming themes. The changing stigma and learning more about failure theme was due to the epiphanies described above. Entrepreneurs now saw failure experiences as part of a life journey but, not forgetting how painful the stigma had been, started to think about how they might change failure stigma to minimize its impact on other entrepreneurs who were at risk of failure. They were motivated to change or dispel the notion of venture failure as a final, negative end to an entrepreneurial career. They took actions to challenge the stigma of failure and shift others' thinking about failure as described in the following section.

Part of this first theme is also learning more about failure. Entrepreneurs realized that they had learned a great deal from their failure experience and developed a keen desire to share this knowledge with others. They also wanted to learn more about failure and, in particular, how 
to prevent it. For example, David "wanted to learn more" about why he went bankrupt and also expressed a desire to "give something back" to the business community, despite his bankruptcy. He wished to help other entrepreneurs understand that "although failure was an awful experience...it does not have to be this bad... and there are things that can be done to stop failure". He also wanted to help other failed entrepreneurs get "back on their feet". Caleb was "far more determined" to learn about where and why he had gone wrong in the venture and how he could do better in the next venture. Nigella wanted to learn more about "different processes and systems" in running a small business.

The second theme concerned entrepreneurs taking pride in hard but ethical decisions. Entrepreneurs ultimately felt proud about what they saw as difficult but principled decisions they made in dealing with venture failure. For some this manifested in pride at not declaring bankruptcy because they viewed it as a dishonest or unethical to get out of paying debts. For example, Bob stated that he was "proud" that he "didn’t opt for bankruptcy” even though "it would have been the easy option”. Similarly, Ken pointed out that even though he went through “financially hard times”, he didn’t declare bankruptcy because he had "no intention of walking away with people's money". Paula also stressed that her "value to behave in an ethical way" was the reason why she didn't opt for bankruptcy even though she lost her house to pay back her failed venture's debts. Tania refused bankruptcy because she had people she "did not want to let down". For others who did declare bankruptcy, they took pride in doing it strictly for business losses, not for having accumulated debt to fund a lavish lifestyle. And Nigella took pride in surviving bankruptcy. She stated that not "everybody could cope with bankruptcy" and emphasized that "going bankrupt was very brave as it takes a lot of courage.... it's a big decision that gets bigger every day.” 
Actions, behaviors and decisions. Our evidence shows how the themes in this episode affected entrepreneurs' actions and decisions. Entrepreneurs took actions trying to change stigma associated with failure, for example. Nigella decided to "openly talk about failure” even though friends and family advised her to "hush it up” and "not go around telling everybody”. She came to see her failure as a "real life experience" and thought that if she talked about it, she could make failure easier for someone else. As such, she felt she "broke stereotypes” about venture failure. Ian "openly shared" his failure experience with others in "the hope that someone would benefit from the story". He thought others could use his story to "turn their lives around".

Entrepreneurs engaged in behavior to pass on the learning they had gained through venture failure. Several participants acted as mentors to pass on learning to other entrepreneurs. Nigella informally “mentored two businesses in setting up processes and paying bills on time”. She used her venture failure experience "to tell them when to say no, when to be careful, and when things can go wrong in the business”. David also acted as an informal mentor and shared his "crisis management lessons that came out of this experience with companies in financial strain and on the brink of bankruptcy.” Matt engaged in more formal mentorship in that he began consulting in the area of “change management”. He consulted for "struggling organizations” and drew strongly upon his learning from his failure experience. Based on his experience, Ian developed and sold “a depression management program that was being increasingly used by others”. His goal was to make others feel “empowered and self-determined again”.

Some of the entrepreneurs started up new businesses and incorporated their learning into those ventures. Paula started up a business “offering business mentoring and coaching for people in the creative industry". She believed that such businesses "have a particular set of challenges different to other businesses” and her experience of kite retail could be helpful in 
"beating some sense into entrepreneurs in the creative industry". Bob founded a new business but is clear he will "let go of the new business" given a particular threshold of losses. Larry and Paula both chalked out "exit strategies" for their new businesses.

The transformation in episode three went beyond entrepreneurs' careers, spilling over into their personal lives. For example, David believed lying had destroyed his venture and his marriage and worked hard in his personal as well as professional life to "to answer people’s questions honestly, no matter how hard the questions". Ian decided volunteer in the "more meaningful” area of mental health, given his bout of depression that followed his venture's failure.

In sum, although stigmatization of venture failure was a very negative experience in the first two episodes of the collective story of these entrepreneurs, the third episode illustrates a transformation in how entrepreneurs viewed failure and the stigma associated with it. This transformation was reflected in their career choices, the new ventures they founded, their contribution to other businesses, as well as in their personal lives. It is clear that participants saw the failure as a life altering experience but, in this episode, the meaning attached to this experience was positive and entrepreneurs valued the ways in which their lives had been altered. Importantly, they valued the knowledge gained and wanted to contribute that knowledge to other entrepreneurial endeavors even if they were not personally founding another venture.

\section{DISCUSSION AND CONCLUSION}

The purpose of this study was to understand stigmatization of venture failure from the perspective of individual entrepreneurs who have experienced it. In particular, we sought to identify the microprocesses pertinent to stigma failure that underlie the socio-cultural patterns of stigmatization identified in existing research (Begley \& Tan, 2001; Damaraju et al., 2010; Lee et 
al., 2011). We thus implemented a qualitative, narrative approach to address the research question 'How do entrepreneurs experience stigmatization by self and others when their ventures fail?’ Findings showed entrepreneurs experiencing both social and self stigma in the first two episodes of their collective story of entrepreneurial failure: anticipating and trysting failure. In particular, findings revealed that entrepreneurs experienced stigma before ventures actually failed. This finding extends our understanding of when stigma occurs for entrepreneurs since previous research conjectured that stigma set in with actual venture closure (Cardon et al, 2011). Moreover, findings show how the experience of stigma in the first episode likely contributed to venture failure because entrepreneurs engaged in behavior harmful to their ventures in an effort to minimize the experience of stigma. Another important and unexpected finding was that of the epiphanies entrepreneurs experienced regarding their experience of failure stigma. Epiphanies transformed the meaning entrepreneurs' gave to their experience of stigma from negative to positive. Epiphanies inspired entrepreneurs in the third episode of the collective story to take action to neutralize stigma for other failing entrepreneurs and to contribute their learning about entrepreneurship and failure to other venture founders and struggling businesses.

This study has three implications for the wider entrepreneurship literature. First, findings provide a rare glimpse of the positive side of venture failure. Substantial research illustrates the negative and debilitating effects of entrepreneurial failure (Politis \& Gabrielsson, 2009;

Kirkwood, 2007) and certainly the first two episodes reported in this research corroborate such effects. However, findings from the interlude and the third episode show how epiphanies can occur and transform the negative experience of failure stigma into a positive force for change. Specifically, entrepreneurs proactively challenged failure stigma to minimize its effects on others, contributed their learning to help other entrepreneurs, and even started successful 
businesses based on knowledge gained through failure. Current findings thus concur with other research that says stigmatized individuals should not be regarded as passive victims but keen and empowered actors wanting to make useful contributions to their environment (Paetzold et al., 2008, Shih, 2004). As previously stated, this positive finding was unexpected but suggests future research could more systematically investigate positive outcomes of venture failure.

Second, findings have implications for learning from entrepreneurial failure. Our findings suggest that we broaden our focus to consider multiple mechanisms whereby learning from failure is incorporated into economies. Existing research tends to see future venture founding as the mechanism where learning from failure is contributed to society (Cope, 2011; Singh et al., 2007). As such, learning is potentially lost if entrepreneurial failure reduces further enterprising activities as implied by existing stigma research (Begley \& Tan, 2001; Damaraju et al., 2010). However, our findings encouragingly reveal multiple ways in which learning from failure can be contributed to entrepreneurship even if failed entrepreneurs do not found more ventures. In particular, failed entrepreneurs passed on learning through mentoring other entrepreneurs both formally, through consulting and employment, and informally. They also passed on learning through other artifacts they created including new ventures. Future research is needed to further explore these mechanisms and other whereby learning from venture failure is contributed to society.

Third, our findings have implications for venture start ups after failure. Existing research suggests that failure stigma would discourage failed entrepreneurs from founding another venture (Begley \& Tan, 2001; Damaruju et al., 2001; Lee et al., 2011). However, our findings show the range of individual differences that can manifest with respect to stigma's effects on future venture founding. Importantly, evidence illustrates that, for some entrepreneurs, stigma 
actually motivated future venture founding and shaped the kind of venture that was established. Future research could more systematically examine the individual differences suggested by current findings.

We identify two limitation of the present study. First, evidence was collected in one country, New Zealand. Although this design has the benefit of controlling for extraneous factors regarding stigma that might be due to different national cultures (Damaraju et al., 2010), it potentially limits the generalizability of the data. We encourage readers to consider findings as exploratory and to do additional research that will provide rich descriptions of the experience of stigma of entrepreneurial failure at the individual level. Second, there was some variability in the time between venture failure and data collection across entrepreneurs. For some participants failure was more recent than for others such that their descriptions of stigma may be more vivid and contribute to them having a more prominent voice in the collective story. We see this as a caution but not as overly problematic. In particular, Chell (2004) argues that participants generally have good recall of critical experiences such as entrepreneurial failure.

In conclusion, this paper extends research on the stigma of venture failure to the level of the individual entrepreneur and reveals how stigma shapes entrepreneurs actions, behaviors, and decisions before, during, and after venture failure. Our findings show entrepreneurs experiencing epiphanies which enabled them to reinterpret stigma as positive, transformational, and knowledge generating. Moreover, findings indicate mechanisms in addition to further enterprise founding whereby new knowledge and learning are contributed to the economy. Overall, findings show that the experience of venture failure provides a powerful transformational experience for entrepreneurs that policy makers wanting to encourage 
entrepreneurship would be wise to recognize, celebrate, and somehow harness in programs that support entrepreneurial activity. 


\section{REFERENCES}

Begley, T.M., \& Tan, W-L., 2001. The socio-cultural environment for entrepreneurship: A comparison between East Asian and Anglo-Saxon Countries. Journal of International Business Studies, 32(3): 537-553.

Cardon, M.S., Zietsma, C., Saparito, P., Matherne, B.P., \& Davis, C. 2005. A tale of passion: New insights into entrepreneurship from a parenthood metaphor. Journal of Business Venturing, 20(1): 23-45.

Cardon, M., Stevens, C., \& Potter, D. 2011. Misfortunes or mistakes? Cultural sensemaking of entrepreneurial failure. Journal of Business Venturing, 26(1): 79-92.

Cave, F. D., Eccles, S.A., \& Rundle, M. 2001. An exploration of attitudes to entrepreneurial failure: a learning experience or an indelible stigma? Proceedings of the 2001 Babson College-Kauffman Foundation Entrepreneurship Research Conference: Jonkoping, Sweden, May.

Chell, E. 2004. Critical incident technique. In C. Cassell, G. Symon (Eds.), Essential guide to qualitative methods in organizational research: 45-60 Thousand Oaks, CA: Sage.

Cope, J. 2005. Toward a dynamic learning perspective of entrepreneurship. Entrepreneurship Theory and Practice, 29(4): 373-397.

Cope, J. 2011. Entrepreneurial learning from failure: An interpretive phenomenological analysis. Journal of Business Venturing, 26(6): 604-623.

Cope, J., \& Watts, G. 2000. Learning by doing - an exploration of experience, critical incidents and reflection in entrepreneurial learning. International Journal of Entrepreneurial Behaviour and Research, 6(3):104-124. 
Corrigan, P.W., Morris, S., Larson, J., Rafacz, J., Wassel, A., Michaels, P., et al. 2010. Selfstigma and coming out about one's mental illness. Journal of Community Psychology, 38(3): 259-275.

Creswell, J.W. 2007. Qualitative Inquiry \& Research Design: Choosing Among Five Approaches ( $2^{\text {nd }}$ ed.). Thousand Oaks, CA: Sage.

Creswell, J.W. 2009. Research design: Qualitative, quantitative, and mixed methods approaches (3rd ed.). Thousand Oaks, CA: Sage.

Damaraju, N.L., Barney, J., \& Dess, G. 2010. Stigma and entrepreneurial risk taking; http://www2.druid.dk/conferences/viewpaper.php?id=502023\&cf=43; Accessed15 ${ }^{\text {th }}$ November 2012.

Denzin, N. 1989. Interpretive Biography (Qualitative Research Methods Series 17). Newbury Park, CA: Sage.

Efrat, R. 2006. Bankruptcy stigma: Plausible causes for shifting norms. Emory Bankruptcy Developments Journal, 22(2): 481-519.

Eisenhard, K.. \& Graebner, M. 2007. Theory building from cases: Opportunities and challenges. Academy of Management Journal, 50: 25-32.

Elliot, J. 2005. Using Narrative in Social Research: Qualitative and Quantitative Approaches. Thousand Oaks, CA: Sage.

European Commission Enterprise and Industry Group. 2011. Small and medium sized enterprises: A second chance to entrepreneurs; http://ec.europa.eu/sme2chance; Accessed $15^{\text {th }}$ November 2012.

Franks, J., Nyborg, K., \& Torous, W. 1996. A comparison of the US, UK and German insolvency codes. Financial Management, 25(3): 86-101. 
Fife, B., \& Wright, E. 2000. The dimensionality of stigma: A comparison of its impact on the self of persons with HIV/AIDS and cancer. Journal of Health and Social Behavior, 41(1): 50-67.

Frederick, H., \& Chittock, G. 2006. Global Entrepreneurship Monitor Aotearoa New Zealand. Unitec New Zealand's Centre for Innovation \& Entrepreneurship Research Report Series, 4(1). Auckland, New Zealand: Unitec.

Gartner, W. 2007. Entrepreneurial narrative and a science of the imagination. Journal of Business Venturing, 22(5): 613-627.

Garud, R., \& Giuliani, A. 2013. A narrative perspective on entrepreneurial opportunities. Academy of Management Review, 38: 157-160.

Goffman, E. 1963. Stigma: Notes on the Management of Spoiled Identity. Englewood Cliffs, NJ: Prentice Hall.

Hereck, G.M., Gillis, J.R., \& Cogan, J.C. 2009. Internalized stigma among sexual minority adults: Insights from a social psychological perspective. Journal of Counseling Psychology, 56(1):32-43.

Hinchman, L., \& Hinchman, S. 1997. Memory, identity, and community: The idea of narrative in the human sciences. New York: State University of New York.

Huovinen, J., \& Tihula, S. 2008. Entrepreneurial learning in the context of portfolio entrepreneurship. International Journal of Entrepreneurial Behaviour \& Research, 14(3):152-171.

Jack, S.L., \& Anderson, A.R. 2002. The effects of embeddedness on the entrepreneurial process. Journal of Business Venturing, 17: 467-487. 
Kirkwood, J. 2007. Tall Poppy Syndrome: Implications for entrepreneurship in New Zealand. Journal of Management and Organisation, 13(1):366-382.

Knight, M.T. D., Wykes, T., \& Hayword, P. 2003. 'People don't understand': An investigation of stigma in schizophrenia using interpretative phenomenological analysis (IPA). Journal of Mental Health, 12(3):209-222.

Kroska, A., \& Harkness, S.K. 2006. Stigma sentiments and self-meanings: Exploring the modifying labeling theory of mental illness. Social Psychology Quarterly, 69(4): 325348.

Kuruppu, N. Laswad, F. and Oyelere, P. 2003. The efficacy of liquidation and bankruptcy prediction models for assessing going concern. Managerial Auditing Journal, 18(6/7): 577-590.

Lawler, S. 2002. Narrative in social research. In T. May (Ed.), Qualitative research in action: 242-259, London: Sage; Accessed from Ebrary eBooks. Accessed 16 ${ }^{\text {th }}$ May 2011

Lee, S.-H, Yamakawa, Y., Peng, M., \& Barney, J. 2011. How do bankruptcy laws affect entrepreneurship development around the world? Journal of Business Venturing, 26(5): 505-520.

Lieblich, A., Tuval-Mashiach, R., Zilber, T. 1998. Narrative research: reading, analysis, and interpretation. Thousand Oaks, CA: Sage.

Link, B.G., \& Phelan, J.C. 2001. Conceptualizing stigma. Annual Review of Sociology, 27(1): 363-385.

Markowitz, F.E., 1998. The effects of stigma on psychological well-being and life satisfaction of persons with mental illness. Journal of Health and Social Behavior, 39(4): 335-347. 
McKeon, H., Johnston, K., \& Henry, C. 2004. Multinational companies as a source of entrepreneurial learning: Examples from the IT sector in Ireland. Education \& Training, 46(8/9): 433-443.

Paetzold, R.L., Dipboye, R.L., \& Elsbach, K.D. 2008. A new look at stigmatisation in and of organizations. Academy of Management Review, 33(1): 186-193.

Politis, D., \& Gabrielsson, J. 2009. Entrepreneurs' attitudes towards failure: An experiential learning approach. International Journal of Entrepreneurial Behaviour \& Research, 15(4): 364-383.

Polkinghorne, D.E. 2003. Narrative configuration in qualitative analysis. In J.A. Hatch \& R Wisniewski (Eds.), Life history and narrative: 5-24, Taylor \& Francis e-library; Ebrary eBooks. Accessed16 May 2011.

Rasmusen, E. 1996. Stigma and self-fulfilling expectations of criminality. Journal of Law and Economics, 39(2): 519-543.

Richards, L. 2009. Handling qualitative data. Thousand Oaks, CA: Sage.

Richardson, L. 1990. Winning Strategies: Reaching Diverse Audiences. Thousand Oaks, CA: Sage.

Roca, E., 2010. The exercise of moral imagination in stigmatized work groups. Journal of Business Ethics, 96(1): 135-147.

Schnittker, J., \& John, A. 2007. Enduring stigma: The long term effects of incarceration on health. Journal of Health and Social Behavior, 48(2):115-130.

Selden, P., \& Fletcher, D. 2010. "Practical narrativity” and the "real-time story” of entrepreneurial becoming in The Republic of Tea. Entrepreneurial Narrative Theory Ethnomethodology and Reflexivity (ENTER), 1: 51-74. 
Sellerberg, A.-M., \& Leppanen, V. 2012. A Typology of Narratives of Social Inclusion and Exclusion: The Case of Bankrupt Entrepreneurs. Forum: Qualitative Social Research, 13(1); http://www.qualitative-research.net/index.php/fqs/article/view/1453; Accessed 15 December 2012.

Semadini, M., Cannella, A.A., Fraser, D.R., \& Lee, D.S. 2008. Fight or flight: Managing stigma in executive careers. Strategic Management Journal, 29(5): 557-567.

Shepherd, D.A. 2003. Learning from business failure: Propositions of grief recovery for the selfemployed. The Academy of Management Review, 28(2): 318-328.

Shepherd, D.A, Wiklund, J., \& Haynie, J.M. 2009. Moving forward: Balancing the financial and emotional costs of business failure. Journal of Business Venturing, 24(1): 34-148.

Shih, M. 2004. Positive stigma: Examining resilience and empowerment in overcoming stigma. Annals of the American Academy of Political and Social Science, 591: 175-185.

Singh, S., Corner, P., \& Pavlovich, K. 2007. Coping with entrepreneurial failure, Journal of Management \& Organization, 13(4): 331-344.

Smith, R. \& McElwee, G. 2011. After the fall: Developing a conceptual script based model of shame in narratives of entrepreneurs in crisis! International Journal of Sociology and Social Policy, 31(1/2): 91-109.

Sutton, R.I., \& Callahan, A.L., 1987. The stigma of bankruptcy: Spoiled organizational image and its management. Academy of Management Journal, 30(3): 405-436.

Vaillant, Y. \& Lafuente, E. 2007. Do different institutional frameworks condition the influence of local fear of failure and entrepreneurial examples over entrepreneurial activity? Entrepreneurship and Regional Development, 19(4): 313-337. 
Venkataraman, S., Sarasvathy, S., Dew, N., \& Forster, W. 2013. Of narratives and artifacts. Academy of Management Review, 38: 163-165.

Warren, L. 2004. A systemic approach to entrepreneurial learning, Systems, Research and Behavioural Science, 21(1): 3-16.

Wiesenfeld, B.M., Wurthmann, K.A. \& Hambrick, D.C. 2008. The stigmatisation and devaluation of elites associated with corporate failures: A process model. Academy of Management Review, 33(1): 231-251.

Yin, R. 2003. Case study research: Design and methods (3rd edn). Thousand Oaks, CA: Sage. 


\section{Table 1}

\section{Description of entrepreneurs enduring failure}

\begin{tabular}{|c|c|c|c|}
\hline & Background & Venture Description & After venture failure \\
\hline Bob & $\begin{array}{l}\text { Apprentice } \\
\text { carpet layer }\end{array}$ & $\begin{array}{l}\text { Bob started a carpet retail venture with a friend that lasted } 5 \text { years; } \\
\text { wanting self employment and to become a "millionaire". The } \\
\text { venture was almost bankrupt due to poor credit management so Bob } \\
\text { exited with thirty thousand dollars of personal savings left. He } \\
\text { ended the partnership, sold his family home, and paid bills he was } \\
\text { liable for. The venture closed with the partnership breakup. }\end{array}$ & $\begin{array}{l}\text { Bob used the remaining thirty } \\
\text { thousand dollars to start a small } \\
\text { property development business with } \\
\text { his wife. It is a "successful" venture, } \\
\text { making "good money". }\end{array}$ \\
\hline Caleb & Police force & $\begin{array}{l}\text { Caleb started a transport business given a desire to be self employed } \\
\text { and live a financially "comfortable" life. The venture lasted } 3 \\
\text { years. He closed it because inadequate funding translated into } \\
\text { irrecoverable financial losses. }\end{array}$ & $\begin{array}{l}\text { Caleb became "determined" to learn } \\
\text { about managing businesses. He } \\
\text { enrolled at university (accounting) and } \\
\text { wanted to start another business. }\end{array}$ \\
\hline David & $\begin{array}{l}\text { University } \\
\text { student }\end{array}$ & $\begin{array}{l}\text { David started a construction \& property management business that } \\
\text { lasted for } 4 \text { years; motivated by the need for employment and to pay } \\
\text { existing debts. He was “too ambitious" and "expanded the business } \\
\text { too quickly" without adequate funding, staff, and systems. Huge } \\
\text { financial losses led to bankruptcy. }\end{array}$ & $\begin{array}{l}\text { David helped build other businesses } \\
\text { and wanted to start a firm that offers } \\
\text { guidance to bankrupt entrepreneurs. }\end{array}$ \\
\hline Edward & $\begin{array}{l}\text { Employee in tire } \\
\text { recycling }\end{array}$ & $\begin{array}{l}\text { Edward founded a tire recycling business that included retail and } \\
\text { manufacture of tires. It survived } 4 \text { years. He was motivated by a } \\
\text { keen interest in "environmental issues" and financial gains from self } \\
\text { employment. "Inadequate funding” and the high cost of new } \\
\text { manufacturing technology created irrecoverable financial losses. He } \\
\text { closed the venture to avoid bankruptcy and sold the assets. }\end{array}$ & $\begin{array}{l}\text { Edward wanted to re-start this venture. } \\
\text { He collaborated with researchers to } \\
\text { improve the recycle manufacturing } \\
\text { process to improve cost effectiveness. }\end{array}$ \\
\hline Ian & $\begin{array}{l}\text { Marketer in } \\
\text { banking }\end{array}$ & $\begin{array}{l}\text { Ian started a sports retail business that lasted } 5 \text { years, motivated by a } \\
\text { "passion for sport" \& interest in self employment. "Giving away } \\
\text { too many discounts" to customers led to accumulation of heavy } \\
\text { debts. The venture was closed due to irrecoverable financial losses. }\end{array}$ & $\begin{array}{l}\text { Ian worked in a mental health } \\
\text { organization. }\end{array}$ \\
\hline Jana & $\begin{array}{l}\text { Spiritual } \\
\text { counselor }\end{array}$ & $\begin{array}{l}\text { Jana founded a grief gift retail business with a friend to support } \\
\text { people experiencing grief. It closed after } 11 \text { months due partnership } \\
\text { issues and inadequate funding. }\end{array}$ & $\begin{array}{l}\text { Jana was unemployed but looked for a } \\
\text { new partner with whom to restart the } \\
\text { business. }\end{array}$ \\
\hline
\end{tabular}




\begin{tabular}{|c|c|c|c|}
\hline & Background & Venture Description & After venture failure \\
\hline Ken & $\begin{array}{l}\text { Tertiary student } \\
\text { (studied } \\
\text { mushrooms) }\end{array}$ & $\begin{array}{l}\text { Ken started a mushroom retail business that survived } 5 \text { years, } \\
\text { motivated by a "passion for mushrooms" and the need to earn a } \\
\text { living. However, an unexpected and uncontrollable disease killed } \\
\text { the mushrooms, leading to huge financial losses \& business closure. }\end{array}$ & $\begin{array}{l}\text { Ken was unemployed, looking for a } \\
\text { job. He was open to the idea of } \\
\text { starting a business again. }\end{array}$ \\
\hline Larry & $\begin{array}{l}\text { Computer } \\
\text { technician }\end{array}$ & $\begin{array}{l}\text { Larry and partner began a software sales business; wanting self } \\
\text { employment. It lasted } 6 \text { years but “growing too soon” \& partnership } \\
\text { issues created financial losses, forced receivership \& closure. }\end{array}$ & $\begin{array}{l}\text { Larry worked as a sales person and is } \\
\text { "living the dream" after starting a } \\
\text { consultancy business. }\end{array}$ \\
\hline Matt & $\begin{array}{l}\text { Door and } \\
\text { window making } \\
\text { apprentice }\end{array}$ & $\begin{array}{l}\text { Matt and friend started a door \& window making business that } \\
\text { lasted } 1 \text { year. He wanted self employment but partnership issues led } \\
\text { to heavy financial losses and closure. }\end{array}$ & $\begin{array}{l}\text { Matt fashioned a "successful" career } \\
\text { in change management, leadership, } \\
\text { and business consultancy. }\end{array}$ \\
\hline Nigella & $\begin{array}{l}\text { University } \\
\text { student }\end{array}$ & $\begin{array}{l}\text { She started a sun tan boutique to earn a "deposit to buy a home". } \\
\text { The venture lasted } 6 \text { years but financial losses led to bankruptcy. }\end{array}$ & Nigella helped build other businesses. \\
\hline Paula & Artist & $\begin{array}{l}\text { Paula began a kite retail business that lasted } 10 \text { years. She wanted to } \\
\text { earn a living and leverage an interest in kite making. The venture } \\
\text { closed due to losses and accumulated debts. }\end{array}$ & $\begin{array}{l}\text { Paula started another business. It sold } \\
\text { art and consulted with art businesses. }\end{array}$ \\
\hline Tania & Administrator & $\begin{array}{l}\text { Tania founded a dry cleaning business with her husband; desired } \\
\text { self-employment \& financial security. The venture ran } 4 \text { years. She } \\
\text { sold it for a low price after heavy financial losses due to business } \\
\text { relocation and personal sickness almost led to bankruptcy. }\end{array}$ & Tania worked in public service. \\
\hline
\end{tabular}


Table 2

Outcomes influenced by stigma of entrepreneurial failure

\begin{tabular}{|c|c|}
\hline Episodes and respective themes & Outcomes \\
\hline Anticipating Failure & Actions and behaviors arising from stigma led to \\
\hline -Castigating self & - Exacerbating financial loss \\
\hline -Expecting negative judgments & - Avoiding potential help to cope with practical and personal challenges of venture \\
\hline & failure \\
\hline & - Experiencing isolation and loneliness \\
\hline Trysting Failure & Actions and behaviors arising from stigma led to \\
\hline -Perceiving ostracism & - Experiencing breakdown in personal and professional relationships \\
\hline -Doubting judgment & -Thinking about never founding another business again, becoming more risk \\
\hline & averse \\
\hline & $\begin{array}{l}\text {-Remaining in this episode longer than otherwise might have, experiencing } \\
\text { anxiety, fear, and depression }\end{array}$ \\
\hline Transforming stigma & Transformational attempts led to \\
\hline - Changing stigma \& learning & -Seeing venture failure in a more positive light (i.e., had knowledge to share) \\
\hline more about venture failure & -sharing knowledge gained through failures with others through volunteer work \\
\hline $\begin{array}{l}\text { - Pride in hard but ethical } \\
\text { decisions }\end{array}$ & -Starting new businesses (projects) based on knowledge gained though failure \\
\hline
\end{tabular}

